\title{
ÁREA DEGRADADA PELA EXTRAÇÃO DE AREIA: UM ESTUDO DA DERIVAÇÃO DA PAISAGEM NO BAIRRO DO UMBARÁ, CURITIBA-PR
}

\section{Degraded area by the extraction of sand: a study of how it was originated the landscape of the borough of Umbará, Curitiba-PR}

\author{
Idene Maria MOLETTA ${ }^{1}$ \\ João Carlos NUCCl ${ }^{2}$
}

\section{RESUMO}

As atividades relacionadas à mineração são causadoras de enormes alterações na estrutura e na dinâmica da paisagem e, como tal, estão sujeitas ao processo de licenciamento ambiental e à recuperação das áreas degradadas. A legislação que trata da questão exige um Plano de Recuperação de Áreas Degradadas (Prads), desta forma, a questão que se coloca é o que realmente é recuperado. Para tanto, analisouse a ocorrência de uma possível recuperação ambiental em área degradada pela extração de areia. A área de estudo compreende o Parque Ecológico Costa e seus arredores, sito na margem direita do Alto Rio Iguaçu, no bairro do Umbará, parte sul do município de Curitiba-PR. Foi feito um estudo temporal da área para levantar a paisagem original e, posteriormente, verificar as modificações ocorridas no uso e ocupação do solo nos últimos 50 anos. Concluiu-se que não houve recuperação ambiental, mas uma "transformação ambiental", ou seja, uma reabilitação da paisagem que apresenta estrutura, dinâmica e possibilidades de uso pela comunidade, diferentes daquela original e da paisagem dos anos 1950.

\section{Palavras-chave:}

Paisagem original; exploração mineral; alteração da paisagem; reabilitação.

\begin{abstract}
Activities related to mining generate a great deal of changes in the structure and dynamic of the landscape and, as such, they are liable to the process of environmental permission and the recovering of degraded areas. The legislation that deals with the matter demands a Plan of Recovery of the Degraded Areas. But the point in question is what is really being recovered. To achieve this, the possibility of recovering the environment in areas degraded due to the extraction of sand was analyzed. The area of study is the Parque Ecológico Costa and its surroundings, which is located on the right bank of Rio Iguaçu, borough of Umbará, in the South region of Curitiba, State of Paraná. A chronological study was made of the area in order to specify the original landscape, and afterwards to verify changes occurred in the use and occupation of the land during the last 50 years. It was concluded that there had not been an environmental recovery but an "environmental transformation", that is, landscape rehabilitation that has different structure, dynamic and possibilities of use by the community from that of the original one and the landscape of the 50's.
\end{abstract}

\section{Key-words:}

Original landscape; mineral exploration; landscape alteration; rehabilitation.

\footnotetext{
1 Geógrafa, mestre em Geografia, DGEOG/UFPR. E-mail: idenegeo@yahoo.com.br

2 Biólogo, doutor em Geografia Física, professor DGEOG/UFPR. E-mail: nucci@ufpr.br
} 


\section{INTRODUÇÃO}

Em busca de abrigo, conforto e qualidade de vida, o homem passou a explorar os bens naturais. Em primeiro plano utilizou a madeira, depois com novas formas mudou para a alvenaria utilizando os minerais aparentemente inesgotáveis. Com a chegada de novas tecnologias, industrialização e modos de vida, como o individualismo e construções de grandes centros urbanos, a demanda de recursos, principalmente os de uso in natura na construção civil, passou a ser muito grande tornando predatória a exploração mineral, ocasionando transformações irreversíveis nas paisagens.

Mota (1999) menciona que a transformação de um ambiente rural em um meio urbano, por certo, sempre resulta em alterações ambientais. Portanto, compete ao homem procurar adequar o processo de urbanização às características do ambiente existente de modo que os efeitos negativos sejam os mínimos possíveis.

Segundo Kaur et al. (2004), essas alterações ambientais constituem uma mistura de ações autônomas (naturais) e de ações planejadas pelo homem. Geralmente, as paisagens mudam de maneira um tanto caótica, mesmo quando estas ações tentam ser controladas por meio de planejamentos, os quais às vezes não se cumprem.

Entretanto, deve-se ressaltar que a transformação da natureza, pensando-se no maior lucro direto e imediato e com base na crença no avanço tecnológico, vem provocando profundas modificações nos sistemas naturais sem se cogitar a importância do meio natural como componente fundamental para a vida (NUCCl et al., 2003).

O progresso ocorrido entre os séculos XVI e XIX levou a uma falsa percepção de que a Ciência poderia permitir a construção de uma sociedade mais justa, mais livre e mais fraterna e, também, pelo menos assim se acreditava, libertar-se inteiramente da natureza selvagem, fonte de desgostos, restrições e frustrações (MOLETTA et al., 2005); Dorst (1981) observa que aos poucos o naturalista foi sendo substituído pelo engenheiro.

O homem contemporâneo vive na cidade e da cidade, da fábrica e do escritório, num universo de concreto, aço e asfalto; nutre-se de produtos dos campos e pastagens explorados segundo os princípios de uma agronomia que não é tanto arte como técnica e indústria. (DORST, 1981).

Para Hough (1995) os valores tradicionais do desenho que foram conformando a paisagem física de nossas cidades têm contribuído muito pouco com a sua saúde ambiental e a sua concepção como lugares civilizados e enriquecedores da vida. Na sociedade urba- na, há uma separação dos valores ambientais da cidade e do campo, que é reforçada pela tecnologia.

Hough (1995) menciona também que, apesar da diversidade ser ecológica e socialmente necessária para a saúde e qualidade de vida urbana, todos os esforços se dirigem para o esmero com a paisagem urbanizada e supressão do natural, chegando ainda a questionar quais seriam os lugares da cidade que mereceriam uma reabilitação: as paisagens fortuitas, fruto da atuação das forças urbanas e naturais ou as paisagens formais criadas pelo desenho.

Segundo Fávero et al. (2004), até mesmo nas Unidades de Conservação da Natureza, principalmente nas de Uso Sustentável, corre-se o risco de se artificializar a paisagem a fim de se obterem recursos financeiros para a própria manutenção da unidade. Para esses autores, as interferências antrópicas na paisagem, como cultivos, queimadas, pastoreio, estradas, aceiros, trilhas, edificações, presença de espécies exóticas, impermeabilização de solo e linhas de transmissão de energia, entre outras, aumentam o grau de artificialização das paisagens que deveriam aproximar o cidadão da natureza, um dos objetivos das Unidades de Conservação.

É necessário mencionar que a natureza pode executar uma série de funções. Segundo Van der Maarel e Dauvellier (1978, apud DE GROOT, 1992) e Braat et al. (1979, apud DE GROOT, 1992), estas funções são classificadas da seguinte forma:

- Funções de Regulação: relata a capacidade dos ecossistemas naturais e seminaturais em regular os processos ecológicos essenciais e sistemas de suporte da vida, contribuindo para manutenção da saúde ambiental por fornecer ar, água e solo de boa qualidade.

- Funções de Suporte: fornecimento de espaço, substrato ou meio para atividades humanas tais como habitação, cultivo e recreação.

- Funções de Produção: a natureza fornece muitos recursos, para a alimentação e matéria-prima para a indústria, recursos energéticos e materiais genéticos.

- Funções de Informação: ecossistemas naturais contribuem para uma saúde mental fornecendo oportunidades de reflexão, enriquecimento espiritual, desenvolvimento cognitivo e experiências estéticas.

No entanto, o desprezo do ser humano para com a natureza, muitas vezes acompanhado de agressividade, pode ser explicado pela ignorância em relação ao seu funcionamento e os benefícios fornecidos, bem 
como pelos valores da sociedade. Muitos respeitam um campo agrícola, pois resulta da obra humana, mas poucos sentem o mesmo por um recanto selvagem. Um comportamento semelhante pode ser observado no ato de pintar as pedras e as árvores existentes na cidade (MOLETTA et al., 2005).

Nesse contexto da transformação da paisagem, vários conceitos podem ser relacionados ao acompanhamento e avaliação das mudanças no uso e na cobertura da terra, com a criação de um mosaico de unidades de paisagem em diferentes graus de transformações (NUCCl et al., 2003).

Jalas (1953, 1965 apud TROPPMAIR, 1989) sugere o termo hemerobia que significa a dominação e/ou alteração das paisagens. Sukopp (1972 apud NUCCl et al., 2003) diz que hemerobia é a totalidade dos efeitos das ações, voluntárias ou não, do ser humano sobre os ecossistemas/paisagens e classifica as paisagens em relação aos graus de naturalidade e de artificialidade, ou seja, de estado hemerobiótico.

Monteiro (1978) faz uso do termo "derivar", ou seja, derivações antropogênicas, para entender as ações do homem na natureza afirmando que a aspiração em compreender os graus de derivação dos sistemas naturais sob o impacto da tecnologia humana traz importantes implicações quanto às possibilidades das sociedades humanas em planejar seu próprio futuro. O autor menciona também que o homem pode interagir negativamente e positivamente nos sistemas naturais.

As ações do homem no meio ambiente consideradas de cunho negativo podem ser relacionadas à degradação da natureza vista como mero fornecedor de recursos em prol do enriquecimento próprio. $E$ as ações tidas como positivas estariam relacionadas a ações para devolver ao ambiente degradado o equilíbrio perdido de forma que este pudesse se regenerar independentemente das interferências humanas.

Portanto, o homem atua como sujeito de transformação da natureza. Sauer (1998, p. 42) coloca que

em sentido cronológico a modificação da área pelo homem e sua apropriação para o seu uso são de importância fundamental. A área anterior à introdução de atividade humana é representada por um conjunto de fatos morfológicos. A forma que o homem introduziu são um outro conjunto.

Este conjunto deve ser relacionado à cultura, pois o homem tem a capacidade de alterar a paisagem natural ao seu bel-prazer.

Para Sauer (1998), é imprescindível a interação entre os elementos naturais e antrópicos para entender a evolução da paisagem, pois esta "está em um processo constante de desenvolvimento ou dissolução e subs- tituição". Como um sistema dinâmico, a paisagem atual é o resultado de processos passados e de uma base para dar forma as paisagens futuras (KAUR et al., 2004). Quanto ao uso e cobertura das terras, Fávero et al. (2004) colocam que dentre os muitos elementos componentes das paisagens a vegetação e os usos das terras são destacados como primordiais e indispensáveis, tanto para entendimento da dinâmica das paisagens, quanto para orientar estratégias de planejamento considerando a melhoria da qualidade ambiental, porém, dependendo do tipo de paisagem as formas do relevo constituem-se em elementos de grande importância.

Entretanto, o avanço fornece ao homem um poder cada vez maior para transformar as paisagens e, atualmente, fala-se até de um novo período geológico para caracterizar a ação do homem sobre a natureza: o "Quinário" ou "Tecnógeno".

A Geologia do Tecnógeno concentra-se no estudo dos produtos gerados diretamente ou influenciados pela atividade humana (depósitos e feições do relevo, ditos tecnogênicos), e também de seus processos geradores específicos, sendo esse o modo de funcionamento da natureza, humanizada ou não. Conforme sintetiza Oliveira (1995 apud PELLOGIA, 1998), a originalidade do Período Tecnógeno, ou Quinário, consiste nas novas coberturas pedológicas e as novas formações geológicas, que se encontram em processo de geração, e que são fortemente influenciadas pela ação do homem.

Esse trabalho foi desenvolvido com base no Planejamento da Paisagem, que apresenta como uma de suas metas o ordenamento dos usos da terra e dos recursos naturais, salvaguardando as potencialidades da paisagem, com o objetivo principal de melhorar a qualidade de vida dos seres humanos. Desta forma, estuda a paisagem com ênfase em seus aspectos naturais e estéticos, procurando conservar as bases naturais para o ser humano em áreas urbanizadas ou não.

O conceito de paisagem adotado é o sugerido por Monteiro (2000), ou seja:

Entidade espacial delimitada segundo um nível de resolução do pesquisador com base nos objetivos centrais da análise, de qualquer modo sempre resultante da integração dinâmica, portanto instável, dos elementos de suporte e cobertura (físicos, biológicos e antrópicos) expressa em partes delimitáveis infinitamente, mas individualizadas por meio das relações entre elas, que organizam um todo complexo (sistema), verdadeiro conjunto solidário e único, em perpétua evolução.

E também o de Bertrand (1972): 
A paisagem não é simples adição de elementos geográficos disparatados. É, numa determinada porção do espaço, o resultado da combinação dinâmica, portanto instável, de elementos físicos, biológicos e antrópicos que, reagindo dialeticamente uns sobre os outros, fazem da paisagem um conjunto único e indissociável, em perpétua evolução.

Concordando com TROPPMAIR (2004), pode-se afirmar que "para a Geografia, a paisagem é um dos termos mais fundamentais e importantes, pois ela representa concretamente a fisionomia da estrutura, as inter-relações (dinâmica) e a evolução (tempo) que ocorre em determinada área".

A preocupação com o Planejamento de Paisagem na Alemanha é anterior à Segunda Guerra Mundial tendo suas raízes históricas no "embelezamento da paisagem" que durou até os primeiros anos do século XIX.

Segundo Nucci (2001) na Alemanha pós Segunda Guerra Mundial, o Planejamento da Paisagem teve um papel muito importante na reconstrução do país destruído. As universidades foram estimuladas a abrir programas de "arquitetura da paisagem" com o propósito de combinar os aspectos tradicionais do embelezamento da paisagem com as novas questões relacionadas com a proteção dos recursos naturais, já que a intensificação dos usos da terra e crescimento da demanda de energia causou severos impactos nos ecossistemas.

O Planejamento da Paisagem na Alemanha seria um instrumento de proteção e desenvolvimento da natureza com o objetivo de salvaguardar a capacidade dos ecossistemas e o potencial recreativo da paisagem como partes fundamentais para a vida humana e, segundo Kiemstedt e Gustedt (1990) e Kiemstedt et al. (1998), suas metas seriam:

- $\quad$ salvaguardar a diversidade animal e vegetal e suas biocenoses por meio do desenvolvimento de uma rede interligada de áreas protegidas, renaturalização de cursos d'água, revegetação, reflorestamento, etc.;

- $\quad$ salvaguardar as paisagens, seus elementos e os espaços livres em áreas urbanas para fornecer a oportunidade de contato contemplativo e recreativo na natureza em contraste com as atividades recreativas comerciais, sendo que essas áreas precisam ser designadas e protegidas do impacto visual, dos ruídos e da poluição;

- salvaguardar o solo, a água e o clima por meio da regulamentação de seus usos e regeneração dos recursos, controle do escoamento superficial, da permeabilidade dos solos, dos aqüíferos e da poluição utilizando a vegetação como forma de controle;

- definir recomendações sobre a qualidade da natureza e das paisagens, e metas de qualidade ambiental como subsídio à Avaliação de Impactos Ambientais.

Portanto, o Planejamento da Paisagem está diretamente relacionado com o planejamento do espaço em diferentes escalas, sempre levando-se em consideração a proteção da natureza e o manejo da paisagem, com orientação ecológica e visão interdisciplinar, contribuindo também com os outros setores do planejamento (NUCCl, 2001).

Pode-se citar como propostas metodológicas dentro do campo do Planejamento da Paisagem a de McHarg (1971) que procura incorporar os fatores do meio físico no planejamento com o mapeamento dos fatores intrínsecos do meio natural (clima, hidrologia, geologia, solo e hábitat da vida selvagem) e, depois, combinando os mapas dentro de uma simples composição que indica (por cores e tons usados por vários fatores) a susceptibilidade intrínseca da terra por vários usos, tal como residencial, comercial, industrial, conservação e recreação ativa ou passiva; em adição, a composição indica áreas sobre o terreno onde mais de um uso pode ser suportado.

GÓMEZ OREA (1978) em estudos de planejamento para a localização espacial das atividades para a província de Madrid tem também como base a capacidad de acogida del território, conceito que significa a tolerância do território para acolher os usos do solo objeto de localização, sem que se produzam deteriorações irreversíveis por sobre os limites toleráveis.

Outros trabalhos também apontam a idéia da necessidade de limitar a utilização antrópica da paisagem considerando que o meio natural apresenta fragilidades, como o trabalho de Nucci (2001) desenvolvido em um bairro do município de São Paulo.

Laurie (1975), arquiteto paisagista de Berkeley (Califórnia), também estabeleceu uma base teórica para o planejamento da paisagem, que permite sua aplicação tanto em escala regional como para um jardim, incluindo todos os níveis escalares. A idéia fundamental gira em torno de um processo que sintetize os dados ecológicos e sociais com o fornecimento de uma política sobre o uso do solo ou formas concretas de desenho.

Baseado em sua teoria, Laurie (1975) pensa em compreender os processos naturais que compõem e têm estruturado a paisagem, e os processos sociais que representam, ou resultam, da utilização da paisagem, assim como a forma de percepção. Avança, também, nos métodos para a análise, avaliação, síntese e reso- 
lução de problemas. E, por último, exige-se uma técnica que organize a solução, para que essa possa ser colocada em prática.

Para elaborar o planejamento da paisagem Laurie (1975) segue os seguintes passos:

1. investigação e análise dos fatores ecológicos-paisagísticos; fatores humanos, socioeconô-micos e culturais;

2. avaliação da paisagem em parâmetros econômicos, estéticos e ecológicos;

3. política ou solução de desenho;

4. realização.

O Planejamento da Paisagem pode ser entendido como o processo positivo que pretende acomodar certos usos nas terras com melhores capacidades de acolhimento para eles, e como um processo negativo que pretende evitar a deterioração ou consumo dos recursos naturais, como o solo agrícola e a água de boa qualidade (LAURIE, 1975).

Quanto à importância do Planejamento da Paisagem, até mesmo em áreas urbanizadas, Mota (1999) lembra que no passado o planejamento urbano realizou-se considerando principalmente os aspectos sociais, culturais e econômicos, e admitindo que o ambiente físico deveria adequar-se às atividades do homem. Considerava-se que os recursos naturais poderiam ser utilizados e alterados de forma ilimitada, desde que fossem atendidas às necessidades básicas dos moradores das cidades: habitação, trabalho, circulação e lazer. E complementa, que os problemas ambientais que resultaram desse tipo de planejamento, causando degradação dos recursos naturais, com reflexos negativos sobre a própria qualidade de vida do homem, serviram para mostrar que as leis da Natureza devem ser respeitadas na ocupação de uma área (MOTA, 1999).

Nucci (2001), parafraseando o professor Felisberto Cavalheiro, ressalta que é necessário planejar com a natureza, tentando retirar o máximo proveito do que ela pode fornecer, já que um dos principais propósitos do Planejamento da Paisagem é minimizar a poluição no ambiente e reduzir o consumo de energia. Desta forma, propondo a melhoria da qualidade de vida do cidadão habitante das cidades.

Considera-se que além do levantamento da paisagem original e do diagnóstico da paisagem atual, re- lacionando com as características fundamentais do Planejamento da Paisagem, pode-se, também, sugerir cenários futuros de acordo com o tipo de desenvolvimento imaginado para a paisagem em questão.

Nesse contexto, o trabalho teve como objetivo geral evidenciar as transformações da paisagem causadas pela atividade extrativa da areia e da argila, verificando pontos negativos e positivos na reabilitação ambiental na área do Parque Ecológico Costa no bairro do Umbará, Curitiba-PR.

Para tanto, foi realizada uma reconstituição da paisagem original da área de estudo, e foram verificadas as alterações efetuadas na paisagem nos anos de 1950, 1972 e 2002, comparando-as com a paisagem atual, e de acordo com os dados obtidos, foi avaliado se houve ou não recuperação.

\section{LOCALIZAÇÃO E DESCRIÇÃO GERAL DA ÁREA DE ESTUDO $^{3}$}

A área de estudo compreende 337,1 ha abrangendo o Parque Ecológico Costa, com uma área aproximada a 136 ha, e também seu entorno, pela significativa degradação ambiental ocorrida na paisagem. Localiza-se na margem direita do Alto Rio Iguaçu no bairro de Umbará parte sul do município de Curitiba capital do Estado do Paraná e divisa com o município de Fazenda Rio Grande-PR nas latitudes $25^{\circ} 35^{\prime} 49^{\prime \prime}$ e $25^{\circ} 36^{\prime} 54^{\prime \prime}$ Sul e longitudes $49^{\circ} 18^{\prime} 45^{\prime \prime}$ e $49^{\circ} 15^{\prime} 45^{\prime \prime}$ Oeste de Greenwich (Figura 1).

Os limites do bairro, segundo o Instituto de Pesquisa e Planejamento Urbano de Curitiba (IPPUC ), têm início na confluência da Rua Nicola Pellanda e Estrada do Ganchinho. Segue pela Estrada do Ganchinho, Rua Eduardo Pinto da Rocha, Rio Ponta Grossa, Rio Iguaçu, Arroio da Prensa, Ruas Bortolo Pellanda, Nicola Pellanda, até o ponto inicial. Tendo como vias de acesso a Rodovia 116 sentido Santa Catarina altura do km 111 e a Via Rápida sentido centro-bairro. Ocupa uma área de 2.238 ha. A população de acordo com o censo 2000 (Instituto Brasileiro Geográfico e Estatístico - IBGE) é de 14.700 habitantes.

O bairro do Umbará faz parte da grande unidade geomorfológica denominada Primeiro Planalto Paranaense. Como característica marcante, destaca-

\footnotetext{
${ }^{3}$ Para o trabalho realizado, utilizou-se fotos aéreas de diferentes datas e escalas de levantamento aéreo. Como o objetivo do trabalho consiste em discutir as alterações ao longo de períodos de tempo, tornou-se conveniente a adoção de uma escala de elaboração comum ao trabalho de mapeamento das informações dos diferentes períodos. Deste princípio adotou-se a escala de 1:12000, pois esta escala, além de permitir a impressão em uma folha de tamanho A4, também respeita as escalas das fotos aéreas de 2002 (1:8000) e 1972 (1:10000), ficando generalizadas somente as informações referentes às fotos aéreas do ano de 1950 (1:25000), pois neste caso a escala da foto aérea é muito menor de que a escala de mapeamento.
} 
MOLETTA, I. M.; NUCCI, J. C. Área degradada pela extração de...

FIGURA 1 - LOCALIZAÇÃO DA ÁREA DE ESTUDO

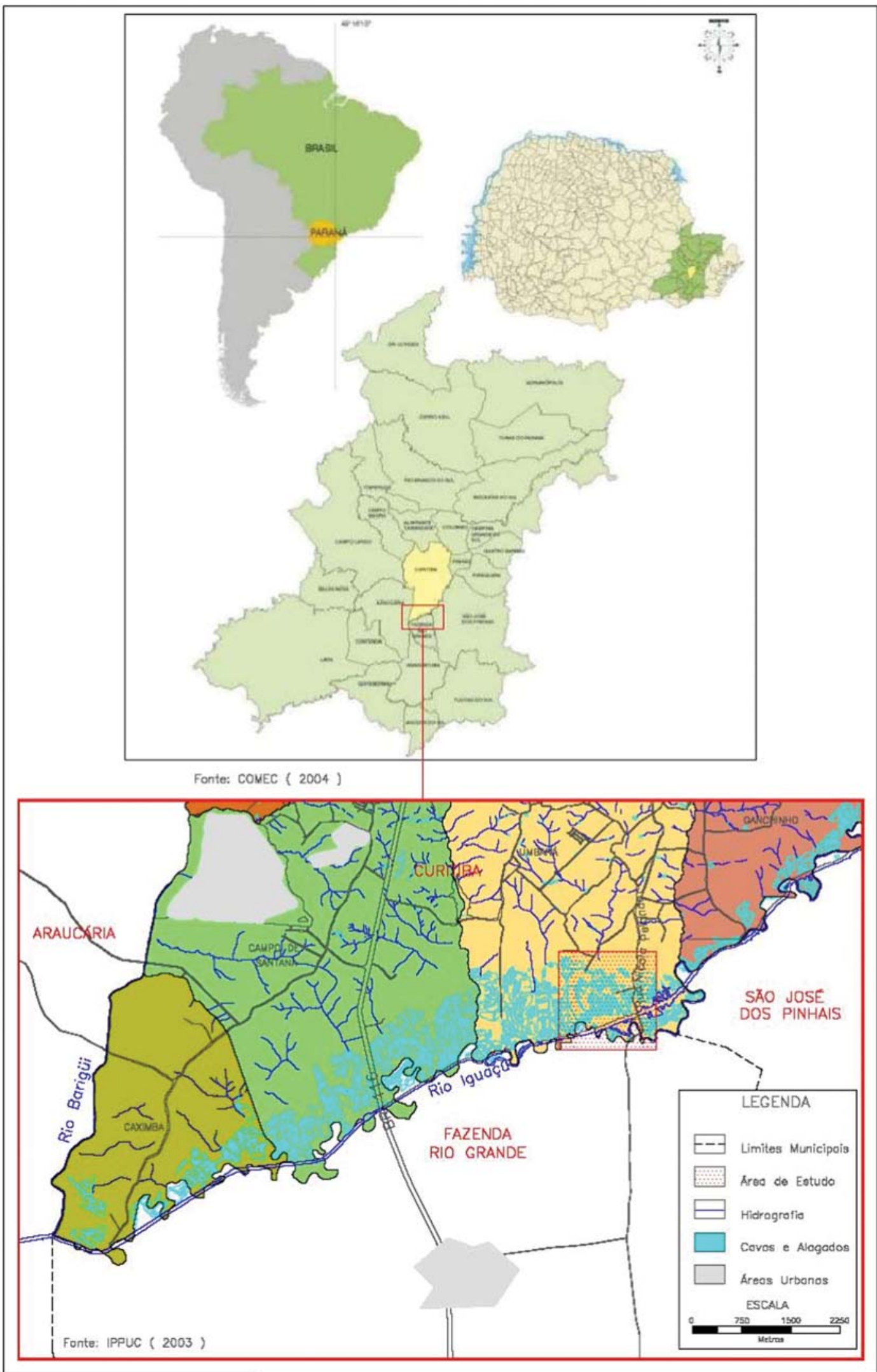


se a extensa planície do Alto Rio Iguaçu, a qual é ladeada por um relevo com formas suavemente onduladas a onduladas, características da Formação Guabirotuba e Embasamento Cristalino. O clima local, segundo a classificação de Köppen, é Cfb, subtropical úmido, com geadas severas e freqüentes na estação seca.

Segundo o Ippuc, em valores absolutos o bairro Umbará é o primeiro em áreas verdes do município de Curitiba, com 7.781.419,93 $\mathrm{m}^{2}$. Já em valores relativos está em décimo terceiro com $34,62 \%$ da sua área total coberta por áreas verdes e apresenta $533,16 \mathrm{~m}^{2}$ de áreas verdes por habitante (dados levantados em 2000). O bairro ainda apresenta um pouco das características rurais, devido às pequenas chácaras existentes, que vão mesclando aos poucos com as características urbanas relacionadas aos conjuntos habitacionais construídos.

A origem do nome do bairro tem duas versões: a primeira consta que o nome Umbará surgiu em conseqüência da constituição argilosa do solo da região, que em tempos de chuva formava grande quantidade de barro nos caminhos "um bará", ou seja, um barro só, segundo a tradição oral dos descendentes, em sua maioria, de italianos e poloneses. E a segunda versão levantada recentemente pelo o historiador Marcos A. Zanon diz que o nome é de origem tupi e que os indígenas utilizavam a palavra Umbará para designar as pequenas frutas silvestres quando começavam a amadurecer.

\section{MÉTODO}

O trabalho tem como base teórica o Planejamento da Paisagem, o qual se constitui em um importante instrumento para a organização do espaço, com o objetivo de salvaguardar e desenvolver as funções ecológicas e estruturais dos espaços, proporcionando melhor qualidade de vida para os seres humanos. Foi também utilizado o conceito de paisagem segundo Bertrand (1972) e Monteiro (2000) pela visão integradora da paisagem envolvendo fenômenos naturais e antrópicos, e o conceito de Derivações Antropogênicas da Paisagem proposto por Monteiro (1978) com a proposta de compreender os graus de derivações dos sistemas naturais ocasionados pela tecnologia humana.

Fazendo-se uso da proposta por Troppmair (1988), que consiste em reconstituir a cobertura vegetal originária para levantar dados ambientais importantes e que foram alterados pelo homem, levantou-se as características da paisagem original destacando as muitas alterações ocorridas abrangendo um período de aproximadamente 55 anos.

Foram organizados mapas de uso e cobertura do solo em papel vegetal utilizando o procedimento de in- terpretação de fotos aéreas nas escalas: 1:25000 de 1950 em preto e branco, obtida na Secretaria Municipal do Meio Ambiente (SMMA); 1:10000 de 1972 em preto e branco; e 1:8000 de 2002 colorida, obtidas no departamento de planejamento do Ippuc.

Após a confecção dos mapas de uso e cobertura do solo em papel vegetal, dos anos de 1950, 1972 e 2002 na escala 1:8000, que permitiu a identificação da fisionomia da cobertura vegetal e outros usos, foi elaborada a legenda de cada mapa com base nas informações obtidas da Planta Fitogeográfica dos arredores de Curitiba, confeccionada por Doubeck, Bigarella e Klein (1952), do Manual Técnico da Vegetação Brasileira (IBGE, 1992), do trabalho de Barddal (2002) e do trabaIho de Leite (1994), complementado com nove idas a campo.

Em seguida, os mapas foram digitalizados por um processo de transformação de imagem analógica (mapa em papel) em imagem digital, por meio da digitalização por scanner na escala de 1:12000, também utilizandose a ferramenta de desenho CAD.

Como foram utilizadas fotos aéreas de diferentes datas e escalas de levantamento aéreo, e o objetivo deste trabalho é discutir as alterações ao longo de períodos de tempo, tornou-se conveniente a adoção de uma escala de elaboração comum ao trabalho de mapeamen-to das informações dos diferentes períodos. Desse princípio adotou-se a escala de 1:12000, pois essa escala, além de permitir a impressão em uma folha de tamanho A4, também respeita as escalas das fotos aéreas de 2002 (1:8000) e 1972 (1:10000), ficando generalizadas somente as informações referentes às fotos aéreas do ano de 1950 (1:25000), pois, neste caso, a escala da foto aérea é muito menor que a escala de mapeamento.

Para armazenar os resultados das áreas calculadas, utilizou-se uma planilha eletrônica do software MICROSOFT WORD e EXCEL versão 2003 e a partir dela calcularam-se os percentuais do total da área mapeada que cada nível de informação representava. Com base nos dados gerados, foram elaborados gráfico e tabela que permitiram uma análise mais exata da paisagem em estudo, pois as alterações ocorridas foram levantadas em porcentagens de cada categoria de uso e cobertura do solo.

A fim de analisar o grau das transformações ocorridas na paisagem em questão, foi elaborado um mapa do que provavelmente teria sido a paisagem original com ênfase na vegetação. Para tanto levou-se em consideração o conceito de Vegetação Natural Potencial contido no trabalho de Fávero et al. (2004), que consiste na máxima expressão que a vegetação atingiria se tivesse a liberdade de se desenvolver sem a interferência do 
ser humano, considerando os atuais limites dados pelo clima e pelas condições edáficas.

Também do conjunto de informações obtidas, ou seja, foto aérea de 1950, carta topográfica, mapas, gráficos, relatos, observações da Planta Fitogeográfica dos arredores de Curitiba confeccionada por Doubeck, Bigarella e Klein (1952), do Boletim da Universidade do Paraná $n^{\circ} 4$ análise de Klein e Hatschbach (1962), do trabalho de Barddal (2002), do levantamento florístico feito por Piaskowski (1994), e análise realizada nos núcleos remanescentes de mata nativa, foi possível, em parte, obter uma idéia aproximada da composição da paisagem original imediatamente anterior à ocupação européia.

Além da interpretação das fotografias aéreas e do estudo bibliográfico, realizou-se levantamento das opiniões dos moradores, das pessoas ligadas à atividade extrativa e das pessoas responsáveis pelas atividades de manutenção do parque ecológico. Para o levantamento dos relatos pessoais, foi necessário escolher os colaboradores com idades variadas que conheceram a paisagem em diferentes épocas, dando-se preferência a pessoas idosas e que usufruíram os benefícios desse ambiente anterior à exploração mineral e vivenciaram as muitas transformações ocorridas até a implantação do parque ecológico. A coleta dos relatos baseou-se na metodologia da História Oral de Thompsom (1992). Os relatos foram gravados com auxilio de gravador digital e transcritos para o papel para tornar o testemunho oral mais preciso.

Por fim, foram realizadas várias pesquisas bibliográficas sobre conceitos e práticas relativos a questões ambientais, a derivação da paisagem, a recuperação de área degradada e a legislação de proteção do meio ambiente e de extração mineral.

\section{RESULTADOS}

\section{PAISAGEM ORIGINAL}

Entende-se por paisagem original aquela que ainda não tenha sofrido grandes intervenções humanas, neste caso, imediatamente anterior à chegada dos imigrantes europeus.

Com base em trabalhos que descrevem a composição da paisagem atual, em comparação com os remanescentes da vegetação e formas de relevo, na carta topográfica, no conceito de Vegetação Natural Potencial (FÁVERO et al., 2004), e nas entrevistas com os moradores entre 50 e 80 anos de idade, pôde-se inferir que a paisagem original estaria estruturada da seguinte forma:
- Geologia representada por rochas do Embasamento Cristalino (migmatitos, granitos de anastesia e gnaisses) de idade PréCambriana e sedimentos Pleistocênicos da Formação Guabirotuba, sobre os quais estariam depositados os sedimentos recentes, representados por argilas e areia inconsolidadas do Rio Iguaçu.

- Relevo com formas suavemente onduladas a onduladas, característico da formação geológica local. As altitudes variariam de $868,1 \mathrm{~m}$ a $868,3 \mathrm{~m}$ nas partes mais baixas e de $869,4 \mathrm{~m}$ a $898,2 \mathrm{~m}$ nas partes mais altas.

- Solos: comumente em áreas ribeirinhas aos cursos d'água, sob as formações ciliares, são encontrados diversos solos, os quais variam essencialmente em função do maior ou menor grau de hidromorfismo, sendo que onde há permanente encharcamento, desenvolvem-se principalmente os organossolos e, em menor proporção, os gleissolos e os neossolos quartezarênico (JACOMINE, 2000). De acordo com Rauen et al., citados por Barddal (2002), os solos representativos da área de estudo são os Organossolos, Gleissolos, Neossolo Flúvico e Cambis-solos. Os dois primeiros são característicos de superfícies planas, levemente abaciadas (bacias de inundação), enquanto os dois últimos são de relevo quase plano.

- Cobertura vegetal composta por vastos campos edáficos, ou campos de inundação (campos hidrófilos e higrófilos), situados nas grandes várzeas do Rio Iguaçu, entremeados por "capões" (pequenos núcleos de vegetação arbustiva e arbórea, de forma quase circular), e por matas de galeria que acompanhariam o rio sujeito a inundações periódicas. Esses campos seriam formados por gramíneas como a Paspalum notatum, a Andropogon virgatus e a Panicum subjunceum, crescendo espaçadamente haveria a Vernonia westiniana (chama-rita ou assapeixe) a Tibouchina ursina, Ciperáceas, destacando-se a Rhynchospora emaciata e a Fimbristylis autumnalis, bem como a pequena Rhynnchospora tenuis. $\mathrm{E}$ espécies como a Baccharis, vulgarmente conhecidas por carquejas, o araçá do campo (Psidium littorale), a embira (Daphnopsis racemosa), Rhamnus polymorpha e a cruz de malta (Jussiaea sericea). 
As estreitas matas de galeria seriam formadas por um pequeno número de árvores de porte médio (Floresta Ombrófila Mista Aluvial), dentre as quais se sobressairia, pela sua abundância, o branquilho ou branquinho (Sebastiania Klotzschiana), constituindo uma vegetação baixa, tendo comumente a altura de 5 metros. Nesse tipo de vegetação também ocorreria agrupamentos irregulares de palmeiras (Arecastrum romanzoffianum) que alcançariam 15 ou mais metros de altura marcando a fitofisionomia das matas de galeria.

De modo geral, os capões de floresta (Ombrófila Mista) seriam compostos pelo pinho brabo (Podocarpus lamberti) nas pequenas colinas e com o pinho brabo, apareceriam nos pequenos capões em vias de sucessão, um grande número de árvores médias, tais como a aroeira (Schinus terebinthifolius), a capororoca (Rapanea ferruginea), a congonha (Citronela paniculata), pessegueiros brabos (Prunus sellowii), erva-mate (Ilex paraguariensis), guabirobeiras (Campomanesia xanthocarpa), e o cambuí (Myrceugenia eunosma). No interior desses capões apontariam exemplares médios do pinheiro-do-paraná (Araucaria angustifolia) crescendo ao lado de um regular número de espécies da família Myrtaceae, predominando geralmente Myrcia Bombycina e Calyptranthes concinna.

A evolução dessa paisagem está intimamente relacionada à drenagem do Rio Iguaçu, que foi responsável pelo espessamento dos depósitos aluvionares (holocênicos) na bacia. De acordo com Maack (2002), "em virtude da queda módica que ocorre na região do primeiro planalto de Curitiba, o rio Iguaçu desenvolveu meandros de curvaturas amplas com águas antigas e com extensas várzeas". A movimentação lateral do rio Iguaçu que ora ocasionava erosão (degradação), ora deposição (agradação), resultou na modificação da morfologia da paisagem, pois ao longo dos anos é característica a migração do canal pelo seu vale, deixando para trás os meandros abandonados.

De fato, uma planície aluvial será sempre uma área de sedimentação em processo, oriunda do transbordamento das águas carregadas de sedimentos nas margens dos rios. As áreas de enchentes são ocupadas por lâminas d'água que variam em extensão e volume, a cada ano ou período. Os rios perenes, situados em baixa declividade, são forçados a meandrar em seu percurso longitudinal e têm uma dinâmica excepcional na triagem dos sedimentos fluviais segundo seu peso e tamanho, durante o período de transborde, sendo que os sedimentos mais grosseiros vão tombando nas mar- gens e os mais finos são projetados para mais longe, no espaço geral das várzeas. É interessante, também, mencionar que de modo geral os rios das regiões intertropicais transportam sedimentos retirados de rochas decompostas ou coberturas pedogênicas situados a montante das planícies independente da distância (AB'SABER, 2000) característica do Rio Iguaçu.

Quanto aos povos que provavelmente ocuparam a região antes da chegada dos europeus, estão grupos indígenas como o Umbu (2000 a.C.) e o Itararé (entre 900 e 1500 d.C.). Essas idades foram adquiridas de acordo com o material antropológico encontrado durante a extração mineral (cerâmicas e flechas), analisado pelo prof. Igor $\mathrm{Chmyz}^{4}$, que afirmou pertencerem a estes povos indígenas. Segundo ele, o grupo Itararé era de índios arredios ao contato com o branco, portanto quando da chegada dos europeus, esse grupo se afastou para o interior do Estado, sendo futuramente substituídos pelos neobrasileiros (caboclos), resultado da miscigenação entre portugueses e índios Tupi-Guarani, que ocuparam a região até a chegada dos imigrantes poloneses e italianos no final do século XIX no então bairro do Umbará.

A Figura 2 apresenta como poderia ter sido a composição e distribuição espacial da cobertura vegetal, dividida em campos e florestas. Sendo que os campos (hidrófilo e higrófilo) ocupariam 152,4 ha, ou seja, 45\% do total da área. Já as florestas compreenderiam 55\% do total, sendo, 92 ha ocupados pela Floresta Ombrófila Mista e 92,7 ha pela Floresta Ombrófila Mista Aluvial, conforme Tabela 1.

Chama-se a atenção para o curso do Rio Iguaçu no mapa da Paisagem Original (Figura 2). Nos mapas de 1950 e 1972 (Figuras 3 e 4) este antigo curso aparece como meandro abandonado. Portanto, levando-se em conta a extraordinária dinâmica do rio, deduz-se que o curso do rio seria da maneira como está demonstrado na Figura 2.

\section{PAISAGEM NO ANO DE 1950}

A descrição da Paisagem de 1950 foi baseada na interpretação da foto aérea de 1950 e dos relatos dos moradores com idade entre 50 a 80 anos.

A sua estrutura é a mesma descrita anteriormente (geologia, solo, relevo). Mas na cobertura vegetal aparecem as primeiras alterações ocasionadas pelo uso e ocupação do solo. $\mathrm{Na}$ análise geral da paisagem, a

${ }^{4}$ Prof. Dr. do Centro de Estudos e Pesquisas Arqueológicas - CEPA/UFPR (comunicação pessoal). 


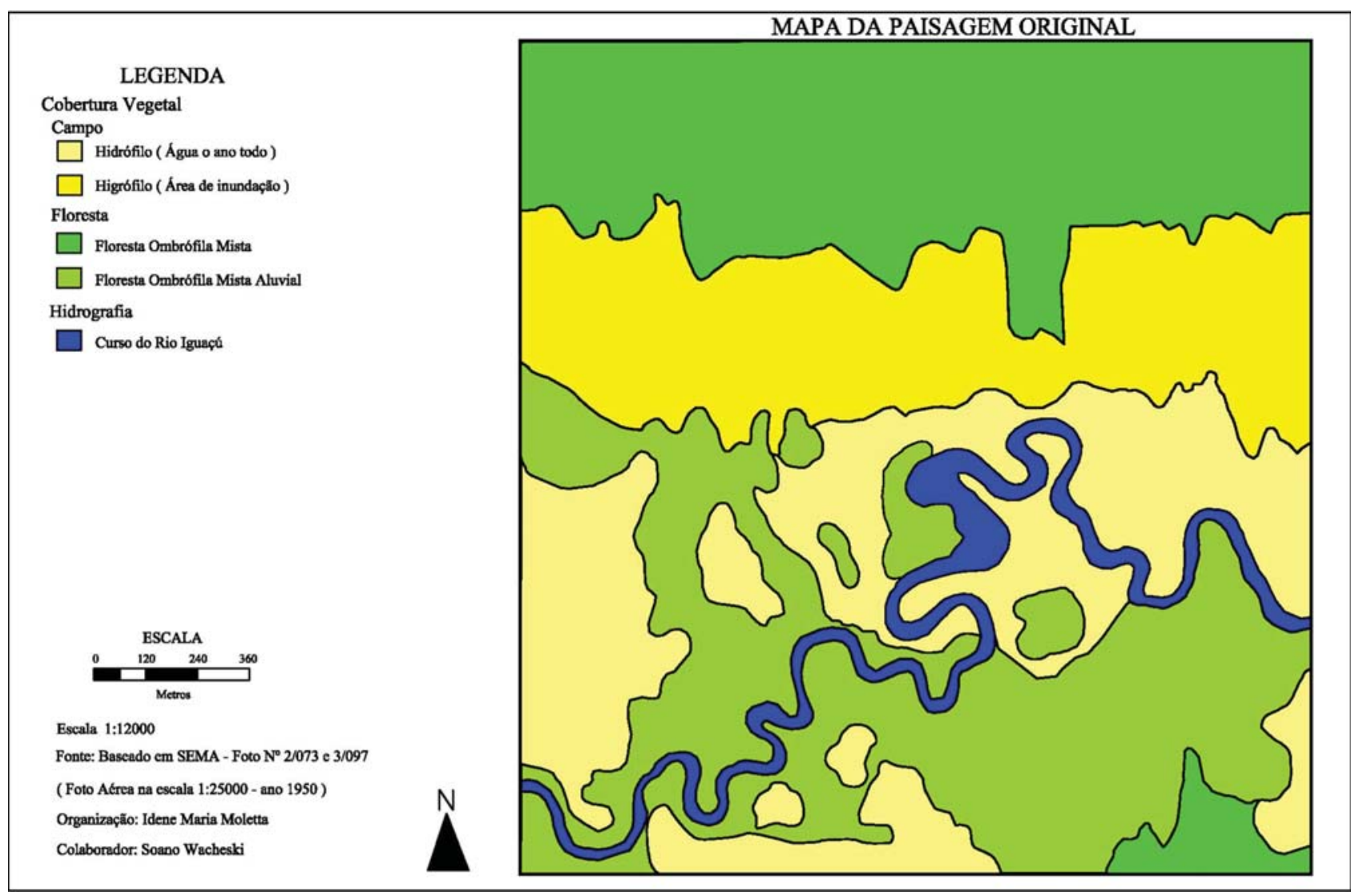

FIGURA 2 - MAPA DA PAISAGEM ORIGINAL

TABELA 1 - ÁREAS DE USO E COBERTURA DO SOLO DA PAISAGEM ORIGINAL E DOS ANOS DE 1950, 1972 E 2002, DO PARQUE ECOLÓGICO COSTA E ARREDORES, CURITIBA-PR.

\begin{tabular}{|c|c|c|c|c|c|c|c|c|}
\hline & Veg. Original (ha) & Veg. Original (\%) & 1950 (ha) & $1950(\%)$ & 1972 (ha) & $1972(\%)$ & 2002 (ha) & $2002(\%)$ \\
\hline Campo Hidrófilo & 81,9 & 24 & 77,5 & 23 & 70,7 & 21 & 0,0 & 0 \\
\hline Campo Higrófilo & 70,5 & 21 & 40,4 & 12 & 33,2 & 10 & 0,0 & 0 \\
\hline Formações Pioneiras* & 0,0 & 0 & 50,5 & 15 & 91,0 & 27 & 111,2 & 33 \\
\hline $\begin{array}{c}\text { Formações Pioneiras } \\
\text { Aluviais }\end{array}$ & 0,0 & 0 & 0,0 & 0 & 0,0 & 0 & 8,3 & 3 \\
\hline Floresta Ombrófila Mista & 92,0 & 27 & 40,4 & 12 & 43,8 & 13 & 26,9 & 8 \\
\hline $\begin{array}{c}\text { Floresta Ombrófila Mista } \\
\text { Aluvial }\end{array}$ & 92,7 & 28 & 80,9 & 24 & 67,4 & 20 & 37,0 & 11 \\
\hline Agrícola & 0,0 & 0 & 43,8 & 13 & 0,0 & 0 & 0,0 & 0 \\
\hline Cavas (espelhos d'água) & 0,0 & 0 & 0,0 & 0 & 19,2 & 6 & 104,5 & 31 \\
\hline $\begin{array}{c}\text { Cavas cobertas por } \\
\text { vegetação }\end{array}$ & 0,0 & 0 & 0,0 & 0 & 0,0 & 0 & 26,9 & 8 \\
\hline Edificações residenciais & 0,0 & 0 & 3,6 & 1 & 7,7 & 2 & 9,1 & 3 \\
\hline Edificações (olarias) & 0,0 & 0 & 0,0 & 0 & 4,1 & 1 & 13,2 & 4 \\
\hline Totais & 337,1 & 100 & 337,1 & 100 & 337,1 & 100 & 337,1 & 100 \\
\hline
\end{tabular}

ORG. MOLETTA, 2005. 
FIGURA 3 - MAPA DE USO E COBERTURA DO SOLO DO PARQUE ECOLÓGICO COSTA E ARREDORES - 1950

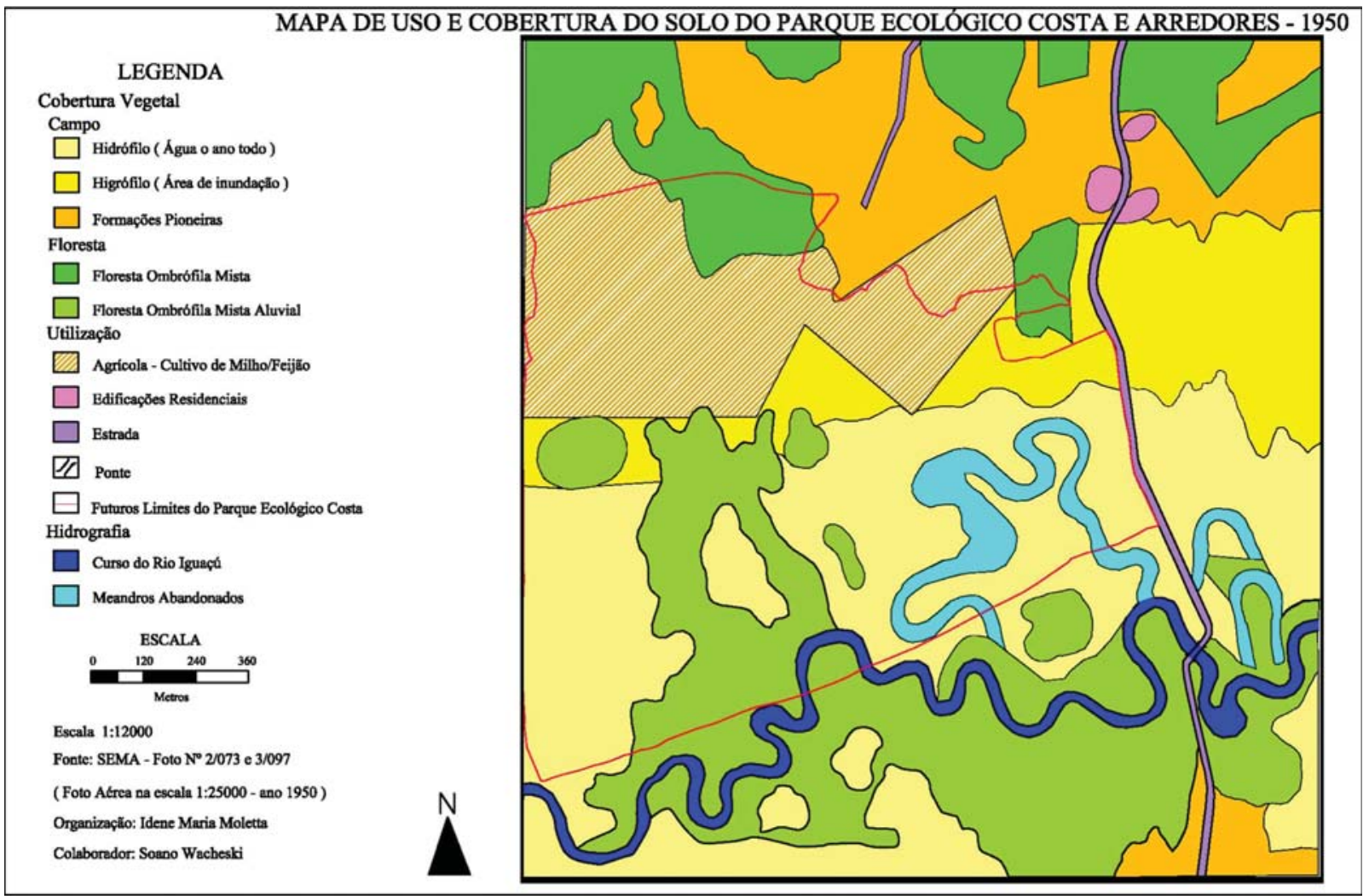

FIGURA 4 - MAPA DE USO E COBERTURA DO SOLO DO PARQUE ECOLÓGICO COSTA E ARREDORES - 1972

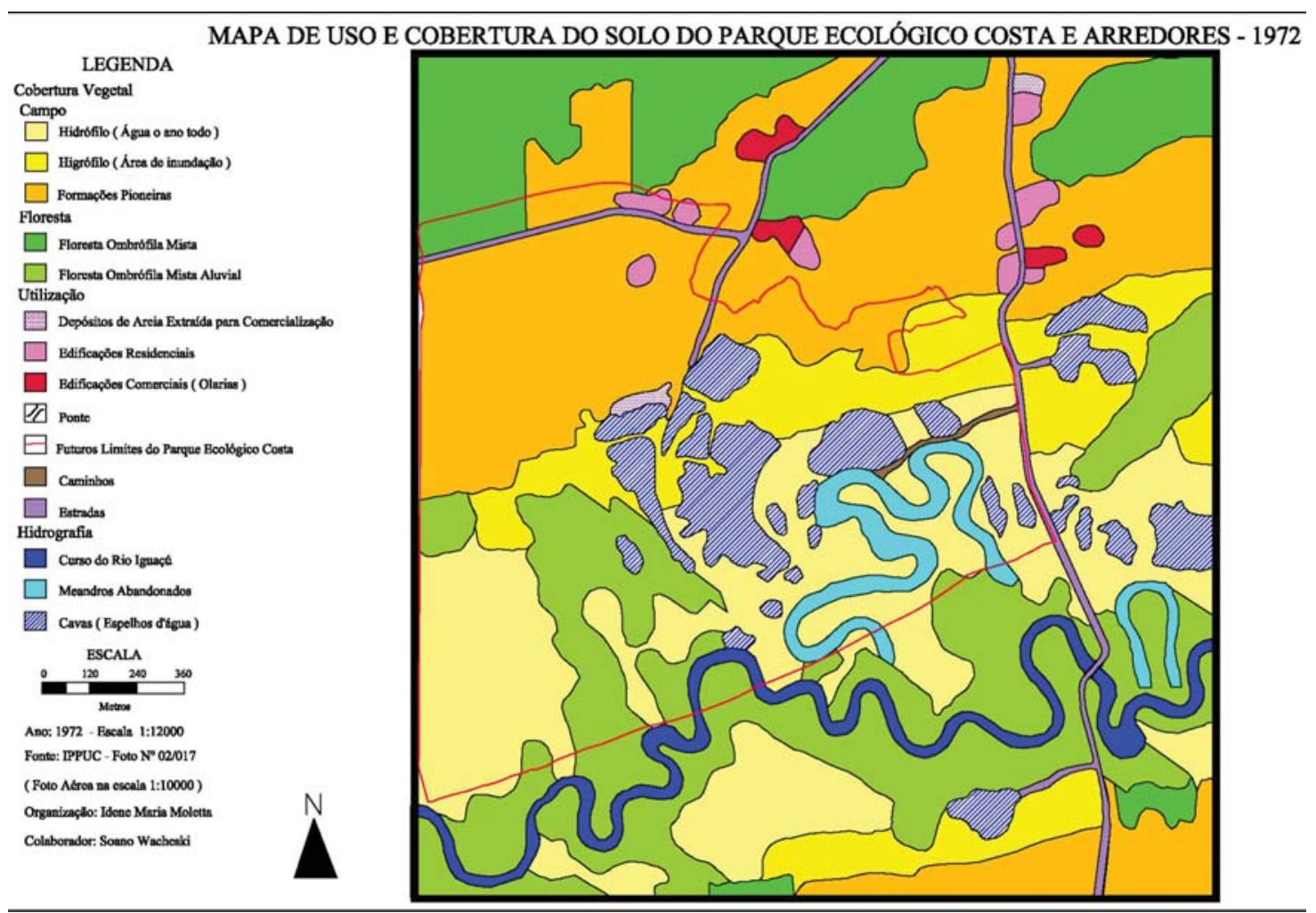


vegetação apresenta um decréscimo de $22 \%$ nos campos originais e $34 \%$ nas florestas, conforme dados da Tabela 1 a composição da paisagem de 1950 (Figura 3) apresenta-se da seguinte forma:

\section{CAMPOS}

- Hidrófilo (água o ano todo): característico de áreas de várzea, coberto por uma vegetação herbácea. Compreende $23 \%$ do total da área, correspondendo a 77,5 ha. Não se apresenta muito alterado em comparação com a paisagem original pelo fato de estar encharcado o ano todo dificultando seu uso, por exemplo, pela agricultura.

- Higrófilo (área de inundação): característico de áreas de várzea, coberto por uma vegetação herbácea é, sobretudo, sujeito a inundações periódicas do Rio Iguaçu. Compreende $12 \%$ do total da área, correspondendo a 40,4 ha. Já apresenta alterações, passando a um decréscimo de $42 \%$ em relação à vegetação de campo higrófilo. Área de inundações periódicas, utilizada para pasto e agricultura.

- Vegetação pioneira ou formações pioneiras: o termo formação pioneira é utilizado para denominar o tipo de cobertura vegetal formado por espécies colonizadoras de ambientes novos, áreas subtraídas naturalmente de outros ecossistemas ou surgidas em função da atuação recente ou atual dos agentes morfodinâmicos e pedogenéticos. As áreas antropizadas, ou seja, alteradas em sua vegetação original, apresentam um processo natural de recomposição da cobertura vegetal, em que observa-se a invasão, em séries sucessionais, das espécies recolonizadoras, em nítido pioneirismo ocupacional (LEITE, 1994). Esse tipo de vegetação compreende uma área de 15\% equivalendo a 50,5 ha, e está substituindo parte da Floresta Ombrófila Mista e do campo higrófilo.

\section{FLORESTAS}

- Floresta Ombrófila Mista: apresenta-se bastante alterada, correspondendo a uma área de 40,4 ha equivalendo a $12 \%$ do total da área, sendo que anteriormente compreen- dia 92 ha, ou seja, $27 \%$ da área total. A floresta foi retirada para o cultivo de feijão e milho, para construção de residências, abertura de caminhos/estradas e obtenção de lenha (cozinhar os alimentos e aquecer ambientes).

- Floresta Ombrófila Mista Aluvial: ocupa uma área de 80,9 ha equivalendo a $24 \%$ do total da área. A Floresta Ombrófila Mista Aluvial é uma formação ribeirinha (Mata Ciliar), que ocupa sempre os terrenos aluvionares situados nos flúvios das serras costeiras ou dos planaltos (IBGE, 1992) e apresenta a espécie Sebastiana commersoniana (branquilho), como uma das mais populares.

Quanto ao uso e ocupação, aparecem na paisagem, no mapa de 1950 (Figura 3), a área de cultivo de milho e feijão ocupando $13 \%$, representando 43,8 ha no total - note-se que esta área se localiza dentro do atual Parque Ecológico Costa -; a estrada (caminho percorrido por alguns viajantes vindos do sul do país e também do porto de Paranaguá-PR); e as primeiras residências de imigrantes de origem polonesa. Observe-se a mudança no curso do Rio Iguaçu, agora com meandros abandonados, demonstrando a dinâmica natural do rio.

\section{PAISAGEM NO ANO DE 1972}

Na paisagem de 1972, conforme Figura 4, surgem significativas alterações. As marcas da extração mineral abrangem $6 \%$ do total da área, correspondendo a 19,2 ha de espelhos d'água (cavas) que substituem a vegetação, o solo e o subsolo. A área antes destinada à agricultura de subsistência é tomada pelas Formações Vegetais Pioneiras. As edificações, comerciais e residenciais, somam agora $3 \%$ da área, equivalente a 11,8 ha. Assim sendo, a composição da paisagem baseada nos dados quantitativos demonstrados na Tabela 1 apresenta-se da seguinte forma:

\section{CAMPOS}

- Hidrófilo: compreende uma área de $21 \%$ do total da área, correspondendo a 70,7 ha. As alterações foram ocasionadas devido aos trabalhos de exploração mineral.

- Higrófilo: compreende uma área de $10 \%$ do total, correspondendo a 33,2 ha. As alterações nesta vegetação são bastante significativas em relação à vegetação original. $A$ degradação nesta formação vegetal foi maior, por se tratar 
de uma área onde ocorrem inundações periódicas. Portanto, o solo não se apresenta o tempo todo encharcado, tornando-o mais suscetível à exploração pelo homem.

- Vegetação pioneira ou formações pioneiras: cobertura vegetal formada por espécies colonizadoras, sua ocorrência nesta paisagem é maior em comparação com a paisagem de 1950 (Figura 3). Abrange 27\% da área, equivalendo a 91 ha. Este fato se dá em decorrência da retirada da vegetação natural, como a Floresta Ombrófila Mista e o campo higrófilo, para usos diversos. Após o abandono da atividade (agricultura e pastagem), é comum a natureza se regenerar, surgindo tais formações.

\section{FLORESTAS}

- Floresta Ombrófila Mista: curiosamente, esta formação vegetal apresenta um pequeno aumento na composição da paisagem sua área de ocorrência passa para 43,8 ha (13\%). Em 1950, sua área era de 40,4 ha
(12\%) correspondendo a um aumento de 3,4 ha do total da área. Este aumento se deve pela não-intervenção do ser humano onde em 1950 ocorriam as vegetações pioneiras. Portanto, em 22 anos, as pioneiras foram substituídas por uma floresta.

- $\quad$ Floresta Ombrófila Mista Aluvial: essa formação ribeirinha passou a ocupar uma área de 67,4 ha o que equivale a $20 \%$ do total da área mapeada. Sofreu pouca degradação porque a exploração mineral foi pequena desde 1952.

As atividades agrícolas, que correspondiam, em meados de 1950, a 43,8 ha, no ano de 1972 (Figura 4) sequer aparecem no mapa; em seu lugar estão as Formações Pioneiras. A causa do abandono das plantações, segundo relatos dos moradores, foram as constantes perdas da lavoura pelas cheias do Rio Iguaçu.

\section{PAISAGEM NO ANO DE 2002}

Pode-se observar no mapa do uso e ocupação do solo no ano de 2002 (Figura 5) uma paisagem quase que totalmente alterada pela ocupação humana, não

FIGURA 5 - MAPA DE USO E COBERTURA DO SOLO DO PARQUE ECOLÓGICO COSTA E ARREDORES - 2002

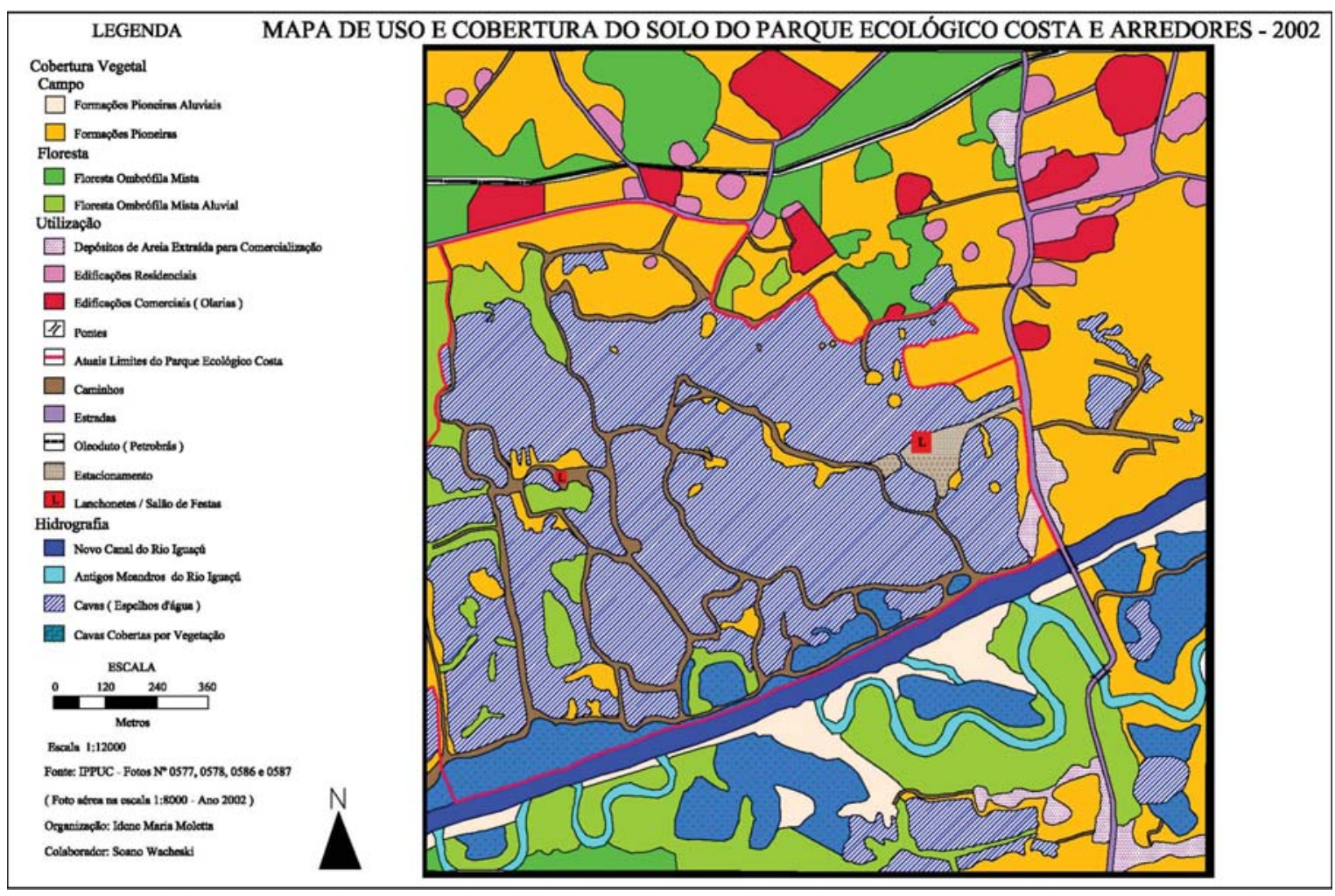


GRÁFICO 1 - ÁREAS DE USO E COBERTURA DO SOLO DA PAISAGEM ORIGINAL E DOS ANOS DE 1950, 1972 E 2002, DO PARQUE ECOLÓGICO COSTA E ARREDORES, CURITIBA-PR

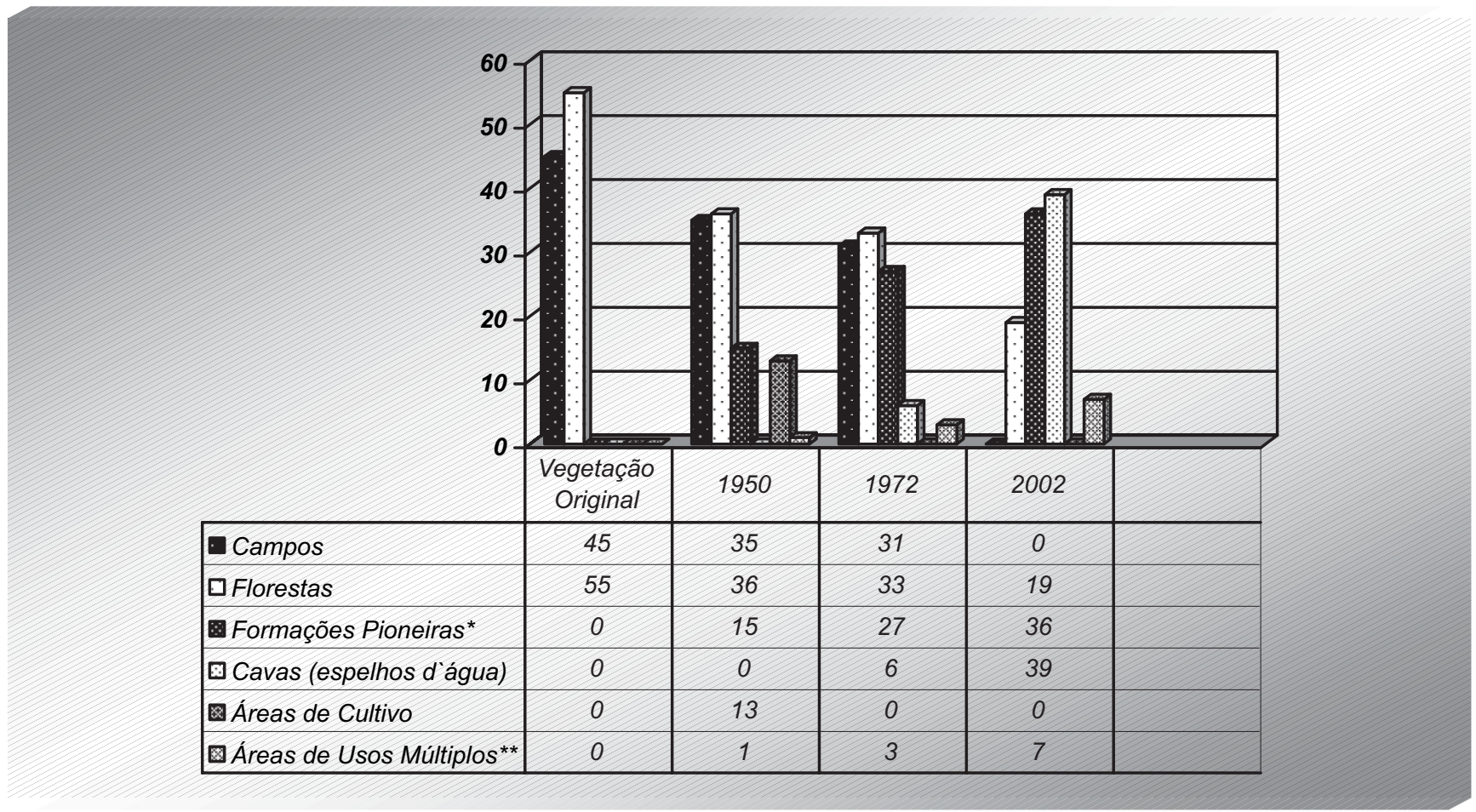

ORG. MOLETTA, 2005.

* O termo formação pioneira é utilizado para denominar o tipo de cobertura vegetal formado por espécies colonizadoras de ambientes novos, ou seja, áreas que foram alteradas em sua vegetação original e que apresentam um processo natural de recomposição da cobertura vegetal.

** Compreende as moradias e as olarias dos vizinhos do parque, o oleoduto da Petrobras, pontes, ruas, depósitos de areia extraída destinada para venda, estacionamento, lanchonete e salão de festas.

fosse pelos remanescentes da vegetação nativa. A seguir são apresentadas as características e a quantificação, em termos de porcentagem conforme Gráfico 1, das categorias de uso do solo de cada item da legenda: Campos Hidrófilo, água o ano todo, e Higrófilo, área de inundação (0\%): característicos de áreas de várzea, cobertos por uma vegetação herbácea, eram sobretudo os campos sujeitos às inundações periódicas do Rio Iguaçu, compreendiam 152,4 ha $(45 \%)$ da paisagem. Estes campos recobriam os sedimentos Holocênicos objeto da exploração mineral por 45 anos. Foram extraídos aproximadamente quatro milhões de metros cúbicos de areia e uma quantidade não-determinada de argila, transformando os campos em inúmeras cavas (espelhos d'água) com dimensões variáveis, separadas por estreitas ou largas faixas de terra, descaracterizando a antiga planície de inundação do Rio Iguaçu.
- $\quad$ Formações Pioneiras (36\%): estas espécies recolonizadoras foram separadas em: Formação Pioneira (111,2 ha) encontrada em áreas de solo antropizado que foram aplainados e Formação Pioneira Aluvial (8,3 ha), que ocupou os aluviões na margem esquerda no canal retificado do Rio Iguaçu, sul do mapa de 2002 (Figura 5), portanto um solo bastante úmido. A vegetação é composta por pequenos arbustos, característicos de capoeiras; a vassourinha (Mimosa ramosissima benth) é uma das espécies que se destacam pelo número de ocorrências.

- Florestas (19\%): a Floresta Ombrófila Mista Aluvial $11 \%$, uma formação ribeirinha (Mata Ciliar) e a Floresta Ombrófila Mista $8 \%$, esta também conhecida como "matade-araucária ou pinheiral". A araucária $(A$. angustifolia), apesar de ser a principal espécie dessa formação vegetal, é representada por poucos indivíduos. Estas florestas 
fazem parte dos núcleos remanescentes da vegetação original que ocupavam 184,7 ha da área total e atualmente se restringem a 63,9 ha, ou seja, houve um decréscimo de $65 \%$ em comparação com a paisagem original.

- $\quad$ Cultivos - Milho e Feijão (0\%): os cultivos de milho e feijão se davam em boa parte da várzea do Rio Iguaçu sendo abandonados em meados da década de 1950 e 1960, devido às enchentes do rio, segundo relato dos moradores. Mas foram as mudanças de hábitos, de atividades comerciais, além, claro, das inundações, as principais causas da mudança de uso. Portanto, já no mapa de 1972 não aparece a área de cultivos e muito menos no mapa de 2002; em seu lugar existem cavas e campo de gramíneas (Pioneiras) que servem de pasto para os cavalos utilizados em passeios recreativos do Parque Ecológico Costa.

- Hidrografia (39\%): compreende as "águas" da paisagem. Na parte sul do mapa de 2002 (Figura 5) está o curso do Rio Iguaçu e os meandros recentemente abandonados em conseqüência da retificação do rio entre 1999-2000. As cavas e cavas cobertas por vegetação, resultado da exploração mineral, compõem boa parte da paisagem, ou seja, 39\%. Dentro da área do parque ecológico, que conforme os mapas de uso e cobertura do solo compreende aproximadamente 136 ha, os espelhos d'água abrangem $80 \%$ da área equivalendo a 108,7 ha e são utilizados para criação de peixes, com caráter conservacionista, para preservação de espécies nativas locais.

- $\quad$ Área de Uso Múltiplo (7\%): compreende as moradias e as olarias dos vizinhos do parque, o oleoduto da Petrobras, pontes, ruas, depósitos de areia extraída destinada para venda, estacionamento, lanchonete e salão de festas.

\section{A DERIVAÇÃO DA PAISAGEM}

Comparando a tabela, o gráfico e os mapas de uso e ocupação do solo, da paisagem original e durante um período de 55 anos, a paisagem em estudo apresentou um elevado grau de transformação.

Considera-se que entre 1950 a 1972 a derivação foi de baixa magnitude, apesar de já aparecerem mar- cas da exploração mineral, pois a cobertura vegetal original que era de 239,2 ha em 1950 passou a 215,1 ha em 1972. Essa diferença para menos pode ser explicada pelo aumento nas formações pioneiras, cavas e edificações. Ressalta-se que a Floresta Ombrófila Mista apresentou saldo positivo de um ponto percentual num período de 20 anos. Esse aumento deve estar relacionado ao abandono da atividade agrícola pelos colonos, pois a floresta ocupou áreas onde apareciam as plantas pioneiras de ocupação no ano de 1950.

No entanto, durante o período entre 1972 a 2002 , a alteração da paisagem foi bastante significativa. De acordo com os dados apresentados na Tabela 1 a cobertura vegetal original, que ocupava $64 \%$ da área total em 1972, reduziu-se a 19\%, correspondendo a 63,9 ha. Os espelhos d'água representam a maior alteração com um aumento de 85,3 ha e em 2002 passam a ocupar 131,4 ha, sendo $39 \%$ da área total. As edificações tiveram um aumento de 10,5 ha, representando agora $7 \%$, ou seja, 22,3 ha de área construída. Observa-se que os dados foram baseados em foto aérea de 2002, portanto, a área construída apresenta novas residências, e também dentro das dependências do Parque foi construído um salão de festas.

A característica meândrica do Rio Iguaçu deu lugar a um canal retificado. Após as catastróficas cheias do verão de 1995, quando milhares de famílias que habitavam as várzeas do Rio Iguaçu na Região Metropolitana de Curitiba ficaram desabrigadas, construiu-se, em medida emergencial, um canal extravasor paralelo à calha do rio (dentro dos limites do município de Curitiba) para escoar o excedente de água que transbordasse o leito normal do rio, reduzindo-se os efeitos das enchentes nos bairros situados a montante. Como a extração de areia ladeando o curso do rio foi intensa nos anos 1980 e 1990, as cavas (espelhos d'água) que foram surgindo com as extrações, a jusante, serviram para espraiar as águas do canal extravasor na junção deste com a calha do Rio Iguaçu. A Coordenação da Região Metropolitana de Curitiba (Comec) considera uma solução definitiva para o problema das enchentes. No que tange às conseqüências da construção desse canal extravasor para os municípios a jusante, seria necessário um estudo especifico, já que a presente pesquisa não abrange tais dados.

Os meandros do Rio Iguaçu, desativados com a retificação do rio, foram cobertos pelas macrófitas aquáticas formando pântanos. Apenas um meandro, dentro da área delimitada, apresenta movimento e deságua no canal extravasor (sudeste do mapa de 2002). Já os meandros abandonados identificados nos mapas de 1950 e 1972 desapareceram. No local, extraiu-se areia e argila, resultando nas cavas (espelhos d'água) que 
ocupam hoje 131,4 ha do total da área, descaracterizando toda a antiga planície de inundação do Rio Iguaçu. Para o doutorando em Engenharia Florestal Murilo L. Barddal (em comunicação pessoal), é a maior degradação da paisagem, pois perdeu-se toda a identidade hídrica da área, que é hoje representada praticamente por um imenso lago artificial.

Nos arredores do parque pertencente a outros proprietários, a vegetação está retornando. Existem áreas que não sofreram degradação, como consta na parte sul do mapa de uso e ocupação do solo de 2002 (Figura 5). Próximo ao canal do Rio Iguaçu, as Formações Pioneiras Aluviais estão preparando o ambiente para as futuras espécies vegetais. Se não houver interferências do ser humano, uma nova mata ciliar poderá se formar.

Percebe-se, portanto, que a mata ciliar foi preservada na parte esquerda do Rio Iguaçu, no município de Fazenda Rio Grande. Ocorreram extrações minerais que não chegaram a degradar totalmente, proporcionando um melhor restabelecimento da vegetação. Como são extrações mais recentes, as leis ambientais devem ter sido aplicadas, pois garantiu-se a preservação da mata ciliar. É curioso, mas, na margem direita do rio, a mata ciliar não foi preservada, portanto levando à conclusão que não foi respeitada a Lei 4.771/65 do Código Florestal, constando também na Legislação Ambiental do Estado do Paraná Art. 118, a qual estabelece a distância igual ou inferior ao equivalente a $10 \%$ (dez por cento) da largura do rio, como se vê no mapa de 2002 (Figura 5). Sendo parte do município de Curitiba, intitulada anos atrás como "a Capital Ecológica", é prova de que as leis ambientais e a fiscalização demoraram a atuar.

Observa-se que as alterações ocorridas nessa paisagem estão ligadas às atividades econômicas dos moradores do bairro. Nos idos da década de 1940 viviase o final das atividades ligadas à exploração da ervamate, tinha-se a agricultura de subsistência, a criação do gado e algumas olarias (indústrias de tijolos), não havendo interferências significativas na paisagem. $\mathrm{Na}$ década de 1950 começam as extrações rudimentares da areia e argila em pequena escala. Em 1972 já aparecem as "feridas" deixadas pela extração mineral, neste momento já com auxílio de máquinas, esse seria o ciclo da extração de areia, que teve o seu auge na década de 1980 e início da década de 1990.

Segundo depoimentos, aproximadamente $90 \%$ dos moradores viveram financeiramente da extração mineral, juntamente com a indústria de tijolos, o que contribuiu para o crescimento comercial e social do bairro do Umbará. Atualmente, apesar das inúmeras atividades comerciais desenvolvidas no bairro, inclusive o turismo devido à implantação do parque ecológico, a extração mineral ainda é fonte de renda para várias famílias locais, que dependem direta e indiretamente dela, mesmo com as jazidas exauridas, com extração mineral em municípios vizinhos.

Deste modo, entende-se que ocorrem aspectos negativos e positivos na transformação da paisagem em estudo. Os aspectos negativos compreendem os seguintes componentes da paisagem: clima/microclima, recurso hídrico, geologia/geomorfologia/solos, vegetação, fauna e patrimônio histórico/cultural/social [sem grifo no original], (adaptado de GRIFFITH, 2003). Portanto, são componentes naturais que foram degradados ao longo de 43 anos de exploração mineral e que hoje apresentam-se completamente modificados, a não ser remanescentes vegetais (fragmentos) que em alguns casos ficaram bastante separados, ou "ilhados", e a fauna, que é composta de várias espécies inclusive vindas de outras localidades em busca de refúgio. Mas, como recuperar os componentes culturais e históricos que ficaram somente na memória dos mais velhos, que os jovens não conhecem e sequer fazem idéia do valor cultural que isso representa?

Os aspectos positivos se resumem em um ambiente voltado para o lazer, entretenimento, contato com a "natureza" - apesar da artificialidade -, e, segundo Wagner Luiz de Oliveira, o zootecnista responsável pela manutenção do parque, "nós conseguimos montar aí um novo ecossistema. Claro que não é o mesmo de cinqüenta anos atrás... seria um neoecossistema".

O parque também é procurado por estagiários de biologia que estudam as aves migratórias e outros animais. Quer queira, quer não, é uma área transformada que foi devolvida para a sociedade com fins de proporcionar momentos de descontração e atividades desportivas (caminhadas, pesca, passeios de barco, entre outras recreações). Foi dada uma nova forma de uso para essa paisagem o qual foi aceita pela comunidade, que vivenciou toda a transformação dela e tiveram uma pequena parcela de participação nessas alterações, em comparação com a atividade extrativa, mas não tiveram oportunidade de opinar sobre os novos destinos da área vizinha. Apesar disso, concordam e vêem como positiva a implantação do parque ecológico.

Essa visão positiva da paisagem atual pelos moradores vizinhos tem duas explicações.

A primeira se deve à visão de desprezo quanto às áreas de várzea. Fato percebido claramente no modo como se referem à paisagem natural, quando se ouviu expressões como: "Ah! era um vargedão só"; "banhado não tinha valor"; "Era um capão ali outro aqui e campo, só campo... banhado".

Existe certa "ignorância ambiental" para com essas áreas. A visão econômica do lucro a qualquer custo 
é considerada mais importante, especialmente quando ainda não se tinha conhecimento do mineral no subsolo. Como relatou Eurides $\mathrm{Costa}^{4}$, anteriormente a área era vista como sem valor econômico, inclusive, quem recebesse de herança uma parte de várzea se lamentava muito, pois não havia como utilizar, ou seja, não dava lucro. Mas, quando da descoberta da areia e o crescente mercado, a várzea passou a ser valorizada. $\mathrm{E}$ o fato da implantação do parque deixou uma visão agradável e ainda de divulgação para outras localidades do Município de Curitiba e Região Metropolitana.

A segunda está voltada para o fato de que a área, antes de sofrer os processos de reabilitação, estava abandonada oferecendo perigo devido à quantidade de cavas (espelhos d'água) e que pescadores faziam algazarras nos fins de semana, tirando a segurança e a tranqüilidade dos moradores vizinhos ao parque. Portanto, os moradores vêem na implantação do parque a resolução de seus problemas.

Em relação aos princípios do Planejamento da Paisagem a área perdeu valor entre os períodos de 1950 e 2002 porque não houve um planejamento adequado para preservar a paisagem original.

Ao se analisar os mapas, percebe-se o poder exorbitante de transformação e degradação pelo homem, que com o passar dos anos alterou não só a paisagem, mas os costumes, a cultura, enfim uma série de atividades que eram executadas pela comunidade.

\section{CONCLUSÃO}

De acordo com os dados obtidos, levantam-se os seguintes resultados:

- $\quad$ Observa-se que as alterações ocorridas nessa paisagem estão ligadas a atividades econômicas desenvolvidas pelos morado- res do bairro (Ciclo da Erva-Mate/Ciclo da Extração de Areia/Comércio-Turismo Ecológico);

- $\quad$ Entende-se que ocorrem aspectos negativos (Alteração de: clima/microclima, recurso hídrico, geologia/geomorfologia/solos, vegetação fauna e patrimônio histórico/cultural/social) e aspectos positivos (Implantação do parque ecológico, área de lazer, manutenção e preservação de espécies animais e vegetais) na transformação da paisagem em estudo;

- O que ocorre na paisagem em estudo é uma "transformação ambiental", ou seja, uma reabilitação da paisagem, com uma nova forma de uso, apresentando estrutura dinâmica diferente daquela original e da paisagem dos anos 1950, é uma nova paisagem, pois não se encontra mais a vegetação campestre típica e a porção florestal se resume a pequenos fragmentos de vegetação formada por espécies exóticas e nativas, descaracterizadas. Entretanto, apesar da artificialidade e das muitas alterações, a paisagem em estudo ainda oferece possibilidades para que os cidadãos desfrutem do contato com a natureza que, em seu conjunto, nos é indispensável. Mesmo sendo uma natureza comprada e muito artificializada para um parque ecológico. Ressalta-se que, anteriormente às transformações ocorridas, não havia custo algum em apreciar a originalidade da paisagem, que infelizmente o homem não soube valorizar, pois o dinheiro passou a ser o fator primordial da sociedade moderna.

\section{REFERÊNCIAS}

AB'SABER, A. N. O suporte geoecológico das florestas beiradeiras (ciliares). In: RODRIGUES, R. R.; LEITÃO FILHO, H. de F. (Ed.). Matas Ciliares: conservação e recuperação. São Paulo: Fapesp, 2000. p.15-26.

BARDDAL, M. L. Aspectos florísticos e fitossociológicos do componente arbóreo-arbustivo de uma Floresta Ombrófila
Mista Aluvial - Araucária (PR). Curitiba, 2002. 91 f. Dissertação (Mestrado em Ciências Florestais) - Setor de Ciências Agrárias, Universidade Federal do Paraná.

BERTRAND, G. Paisagem e geografia física global, esboço metodológico. Revista do DG-FFLCHIUSP - Caderno de Ciências da Terra, São Paulo, n. 13, p. 27, 1972.

\footnotetext{
${ }^{5}$ Eurides Costa, extrator de areia aposentado e proprietário do Areal Costa Ltda. e do Parque Ecológico Costa.
} 
DE GROOT, R. S. Functions of nature: evaluation of nature in environmental planning, management and decision-making. Amsterdam: Wolters-Noordhoff, 1992, p. 315.

DELPOUX, M. Ecossistema e paisagem. Métodos em questão. Tradução de: Modenesi. São Paulo: Instituto de Geografia - USP, 1974, p. 23.

DORST, J. A força do ser vivo. São Paulo: Melhoramentos/ Editora da USP, 1981, p. 175.

DOUBECK, J.; BIGARELLA, J. J.; KLEIN, R. M. Planta fitogeográfica dos arredores de Curitiba - 1952. Boletim da Universidade do Paraná, Curitiba, n. 4, dez. 1962.

FÁVERO, O. A. et al. Vegetação natural potencial e mapeamento da vegetação e usos atuais das terras da Floresta Nacional de Ipanema, Iperó(SP): conservação e gestão ambiental. RA'E GA: o espaço geográfico em análise, Curitiba, n.8, 2004.

GÓMEZ OREA, D. El medio físico y la planificación. Madrid: Cuadernos del CIFCA, 1978.

GRIFFITH, J. J. Duas abordagens para capacitação em recuperação ambiental. In: SIMPÓSIO REGIONAL DE MEIO AMBIENTE: RECUPERAÇÃO DE ÁREAS DEGRADADAS, 2., 2003, Vitória. Anais... Vitória: Ufes, 2003. p. 8-10.

HOUGH, M. Naturaleza y ciudad. Planificación urbana y procesos ecológicos. Barcelona: Gustavo Gili, 1995. p. 315.

IBGE. Manual técnico da vegetação brasileira. Rio de Janeiro, 1992. p. 92. (Manuais técnicos geociências, 1)

JACOMINE, P. K. T. Solos sob matas ciliares. In: RODRIGUES, R. R.; LEITÃO FILHO, H. DE F. (Ed.). Matas Ciliares: conservação e recuperação. São Paulo: Fapesp, 2000.

KAUR, E.; PALANG, H.; SOOVÄLI, H. Landscapes in change - opposing attitudes in Saaremaa, Estonia. Landscape and Urban Planning - Institute of Geography, University of Tartu, Estonia, 2004 p.109-120. Disponível em: <http:// www.elsevier.com/locate/landurbplan> Acesso em: 9/7/ 2004.

KIEMSTEDT, H.; GUSTEDT, E. Landschaftsplanung als Instrument umfassender Umweltvorsoge. 1990. (Conferência internacional).

KIEMSTEDT, $\mathrm{H}$. et al. Landscape planning: contents and procedures. Hanover: The Federal Ministry for the Environment, Nature Conservation and Nuclear Safety, University of Hanover, 1998, p. 39.

KLEIN, R. M.; HATSCHBACH, G. Fitofisionomia e notas sobre a vegetação para acompanhar a planta fitogeografia do município de Curitiba e arredores. Boletim da Universidade do Paraná, Curitiba, n. 4, dez. 1962.

LAURIE, M. Introduducción a la arquitectura del paisaje. Barcelona: Gustavo Gili, 1983, p. 304.

LEITE, P. F. As diferentes unidades fitoecológicas da Região Sul do Brasil - proposta de classificação. Curitiba, 1994. $160 f$.
Dissertação (Mestrado em Engenharia Florestal) - Setor de Ciências Agrárias, Universidade Federal do Paraná.

MAACK, R. Geografia física do estado do Paraná. 3. ed. Curitiba: Imprensa Oficial, 2002. p. 438.

McHARG, I. L. Desing with Nature. New York: Paperback edition/The American Museum of Natural History, 1971, p. 198.

MOLETTA, I. M.; NUCCI, J. C.; KRÖKER, R. Carta de Hemerobia de uma área de extração de areia no bairro do Umbará, Curitiba (PR) - Brasil. In: SIMPÓSIO BRASILEIRO DE GEOGRAFIA FÍSICA APLICADA - GEOGRAFIA, TECNOCIÊNCIA, SOCIEDADE E NATUREZA, 11., 2005, São Paulo. Anais... CD ROM.

MONTEIRO, C. A. F. Derivações antropogênicas nos sistemas terrestres no Brasil e alterações climáticas. In: SIMPÓSIO SOBRE A COMUNIDADE VEGETAL COMO UNIDADE BIOLÓGICA, TURÍSTICA E ECONÔMICA, 1978, São Paulo, Anais... São Paulo: Aciesp, 1978, p. 43-74.

MONTEIRO, C. A. F. Geossistemas: a história de uma procura. São Paulo: Contexto, 2000.

MOTA, S. Urbanização e meio ambiente. Rio de Janeiro: Abes, 1999. p. 352.

NUCCI, J. C. Qualidade ambiental e adensamento urbano. Um estudo de ecologia e planejamento da paisagem aplicado ao distrito de Santa Cecília (MSP). São Paulo: Humanitas/ FFLCH/USP, 2001. p. 236.

$\mathrm{NUCCI}$, J. C. et al. Carta de hemerobia e o grau de naturalidade de ecossistemas urbanizados. In: CONGRESSO DE ECOLOGIA DO BRASIL, 7., 2003, Fortaleza, Anais... p. 110-112.

PELOGGIA, A. O homem e o meio ambiente geológico: geologia, sociedade e ocupação urbana no município de São Paulo. São Paulo: Xamã, 1998.

PIASKOWSKI, S. R. Plano de controle e recuperação ambiental - Areal Costa Ltda. 1994.

SAUER, O. A. Morfologia da paisagem. In: CORREA; ROZENDAHL (Org.). Paisagem, tempo e cultura. Rio de Janeiro: EdUERJ, 1998. p.12-69.

THOMPSON, P. A voz do passado: história oral. 2. ed. Rio de Janeiro: Paz e Terra, 1992.

TROPPMAIR, H. Metodologias simples para pesquisar o meio ambiente. Rio Claro, 1988.

TROPPMAIR, H. Biogeografia e meio ambiente. Rio Claro: edição do autor, 1989, p. 258.

TROPPMAIR, H. Ecossistemas e geossistemas paulistas e ecologia da paisagem. Rio Claro: edição do autor, 2004, p. 130.

ZANON, M. A. Oleiros do Umbará: história e tecnologia (19352000). Curitiba: Tetravento, 2004. p. 173. 